University of Northern lowa

UNI ScholarWorks

Rod Library Faculty Publications

Rod Library

7-8-2021

\title{
Ubiquitous LibGuides: Variations in Presence, Production, Application, and Convention
}

Chris Neuahus

University of Northern lowa

Angie Cox

University of Northern lowa

See next page for additional authors

Let us know how access to this document benefits you

Copyright (C2021 Chris Neuhaus et al.

Follow this and additional works at: https://scholarworks.uni.edu/lib_facpub

Part of the Library and Information Science Commons

\section{Recommended Citation}

Neuahus, Chris; Cox, Angie; Gruber, Anne Marie; Kelly, Jim; Koh, HyunSeung; Bowling, Claire; and Bunz, Gail, "Ubiquitous LibGuides: Variations in Presence, Production, Application, and Convention" (2021). Rod Library Faculty Publications. 19.

https://scholarworks.uni.edu/lib_facpub/19

This Article is brought to you for free and open access by the Rod Library at UNI ScholarWorks. It has been accepted for inclusion in Rod Library Faculty Publications by an authorized administrator of UNI ScholarWorks. For more information, please contact scholarworks@uni.edu. 


\section{Authors}

Chris Neuahus, Angie Cox, Anne Marie Gruber, Jim Kelly, HyunSeung Koh, Claire Bowling, and Gail Bunz 


\title{
Ubiquitous LibGuides: Variations in Presence, Production, Application, and Convention
}

\author{
C. Neuhaus, A. Cox, A. M. Gruber, J. Kelly, H. Koh, C. Bowling \\ and G. Bunz
}

\section{QUERY SHEET}

This page lists questions we have about your paper. The numbers displayed at left are hyperlinked to the location of the query in your paper.

The title and author names are listed on this sheet as they will be published, both on your paper and on the Table of Contents. Please review and ensure the information is correct and advise us if any changes need to be made. In addition, please review your paper as a whole for typographical and essential corrections.

Your PDF proof has been enabled so that you can comment on the proof directly using Adobe Acrobat. For further information on marking corrections using Acrobat, please visit http://journalauthors.tandf.co.uk/production/acrobat.asp; https://authorservices. taylorandfrancis.com/how-to-correct-proofs-with-adobe/

The CrossRef database (www.crossref.org/) has been used to validate the references.

\section{AUTHOR QUERIES}

Q1 Please confirm whether the authors name (including spelling, surname and given name) were identified correctly in "authors group" and "Notes on contributors" section, amend if necessary.

Q2 Please provide complete details for (Thorngate and Hoden 2016 and Ghaphery and White 2012) in the reference list or delete the citation from the text.

Q3 There is no mention of (Bowen 2012, Duncan et al. 2015, Ghaphery \&amp;amp; White 2008, and Thorngate \&amp;amp; Hoden 2017) in the text. Please insert a citation in the text or delete the reference as appropriate.

Q4 Please provide the volume number.

Q5 Please provide the volume number.

Q6 The year of publication has been changed as per Crossref details in the list and in the text for this reference. Please check.

Q7 Please provide the page range. 


\title{
Ubiquitous LibGuides: Variations in Presence, Production, Application, and Convention
}

\author{
C. Neuhaus, A. Cox, A. M. Gruber, J. Kelly, H. Koh, C. Bowling \\ and G. Bunz
}

Rod Library, University of Northern lowa, Cedar Falls, lowa, USA

\begin{abstract}
The LibGuides platform, a content management system (CMS) from Springshare, has become an integral part of the online presence for many academic libraries. Neither Springshare nor other recent studies have provided an in-depth look at the evolving nature of LibGuides adoption, production and application across university and college categories. This study compared the prevalence and production of LibGuides to other forms of library guides at 799 academic libraries throughout the United States. LibGuides naming conventions were recorded and compared. The use of LibGuides CMS software to create library websites was also documented. This study found that there are clear differences in LibGuides adoption and production across various types of institutions. LibGuides naming conventions were fairly consistent across all types of institutions. Institutions using LibGuides software produced substantially more library guides than institutions without this software. A small but significant portion of all non-R1 libraries in this study are now utilizing LibGuides software to create the majority of their library websites.
\end{abstract}

\section{KEYWORDS}

Associate's Colleges; Baccalaureate Colleges; Carnegie Classification; college libraries; Doctoral Universities; LibGuides; library guides; Master's Colleges \& Universities; Springshare; university libraries

\section{Introduction}

LibGuides, Springshare's content management system (CMS), is a widely-adopted platform in academic libraries. Springshare (2021c, para. 1) bills LibGuides as "the most popular, easiest to use web publishing and content curation platform for libraries." The company reports that more than 6,000 libraries of all types use their services (Springshare, 2021a). There are many factors that may account for its popularity, including the platform's flexibility and ease of use for librarians. Despite the widespread use of LibGuides, there is limited research documenting differences in LibGuides adoption in academia. This study seeks to provide a deeper and more nuanced understanding of where and how this popular library resource is being implemented. 
A review of the literature shows several relevant studies, but a consideration of the academic LibGuides landscape could go much deeper and broader. To date, few, if any, studies have documented library guide naming conventions or the relative type and number of libraries using LibGuides software to design their primary websites. While Springshare offers a dashboard for gathering certain statistics (2021c), neither Springshare nor previous studies provide an extensive look at the LibGuides ecosystem in academia across a variety of institution types. This study attempts to more thoroughly delineate and describe the current world of academic LibGuides by examining the following five questions:

Q1. How many of the libraries in this study offer web-based library guides?

Q2. How many libraries use LibGuides software to build their web-based library guides?

Q3. Is there a difference between the average number of library guides produced by libraries using LibGuides software, and the average number of guides created by libraries using other software systems?

Q4. To what extent are libraries using LibGuides to design and build the majority of their library websites and does this differ by type of academic institution?

Q5. What are the primary naming conventions for LibGuides across different types of academic institutions?

\section{Literature review}

While this study examines and describes the continued growth and distribution of LibGuides and LibGuides CMS, a brief review of the library research also provides a sense of the ubiquity of LibGuides, not just in cyberspace, but in the literature as well. Articles on LibGuides are abundant. A title search for "LibGuides" in the database Library Literature \& Information Science Full Text uncovers over 100 articles, while the search "intitle:LibGuides" in Google Scholar yields over 6,000 results with over 100 results published since 2020. LibGuides literature spans a wide variety of topics with particular emphasis on accessibility, design and customization, usability testing, use patterns, and user experience (UX).

Articles that focus on LibGuides design and usability are well represented in the literature. In their LibGuides usability tests, Sonsteby and DeJonghe (2013) found that study participants objected to guides with too many tabs, describing pages as either "cluttered" or "busy." Yelton (2015) pointed to side navigation as a way to declutter a website with too many tabs. Ouellette (2011) shared that students found a left-side navigation menu to be "cleaner" and more "modern." Thorngate and Hoden (2016) found 
that clutter was an impediment to navigation and that students using side navigation outperformed those using horizontal tabbed navigation on various performance tasks. Conerton and Goldenstein (2017) found students preferred guides that required minimal scrolling and contained less text. Lee and Lowe (2018) found that students had a more positive experience when working with "pedagogical-style" LibGuides that were tied to the research process rather than a variety of information formats. Barker and Hoffman (2021) also observed student preferences for side navigation, decluttered library guides, and guides focused on research processes rather than resource types.

Usability research, pedagogical principles, and practitioner advice on library guide layouts and formats have been synthesized and published as best practices in LibGuides design. Gonzalez and Westbrock (2010) advocated for a set of design principles based on a review of the literature, feedback from users, and LibGuides use. Bergstrom-Lynch (2019) recently compiled sets of best practices based on both user studies and instructional design principles. Using an extensive literature review, Goodsett et al. (2020) derived a table of LibGuides best practices that focuses on the six categories of design, navigation, content, accessibility, purpose, and external factors which in turn are subdivided into 30 specific best practices. Both Shotick (2016) and Skaggs (2016) provide advice for designing LibGuides that are accessible to users with visual, mobility, and hearing impairments. Pionke and Manson (2018) note that accessibility is a priority with Springshare, that LibGuides offers many accessibility prompts and features to LibGuide authors, and that the Springshare blog (https://blog.springshare.com/) regularly features updates and advice on making LibGuides more accessible. Despite this, a number of authors caution LibGuides designers to enhance features for accessibility when needed (e.g., adding alternative text to images) and to take advantage of Springshare support (Magnuson, 2015; Pionke \& Manson, 2018). More recently Chee and Weaver (2021) and Hooper (2021) focused on the necessary steps to be taken to help LibGuides comply with the international accessibility standards specified by the W3C consortium's Web Content Accessibility Guidelines (WCAG).

Though much attention has been devoted to LibGuides design and testing, there have also been studies that measured the impact and efficacy of LibGuides on their intended audience. Bowen (2014) compared the relative effectiveness of both web tutorials and LibGuides to successfully present information literacy concepts to students in a communications course. Both the group using web tutorials and the group using LibGuides improved their ability to search for articles and books and to differentiate between scholarly and non-scholarly sources. 
LibGuides may also be having a positive fiscal impact as they are now being promoted as a logical platform for quickly organizing and delivering open educational resources (OERs) to time-strapped faculty and cashstrapped students. Recent librarian initiatives to deliver OERs via LibGuides to specific student audiences appear to be meeting with success (CannonRech \& Mortimore, 2020; Mortimore et al., 2020; Stevens, 2018). A recent study by Hicks et al. (2021) measured the possible role LibGuides play in promoting the use of books. This study showed statistically significant positive correlations between the use of LibGuides and the use of electronic books and the checkouts of print books. To encourage qualitative input regarding LibGuides impact, Pionke and Manson (2018) emphasized the importance of including a "suggestions and comments" option that allows users to provide feedback that can be used by LibGuides authors to improve the content and functionality of library guides over time.

Regarding the adoption of LibGuides by academic libraries, some of the earliest research was conducted by Ghaphery and White (2012), who found that LibGuides software was already used by $68 \%$ of Association of Research Libraries (ARL) libraries in 2011. Jackson and Stacy-Bates (2016) reported similar findings, noting that $72 \%$ of the ARL libraries they reviewed between 2011 and 2013 were using LibGuides software. In their 2014 survey of LibGuides adoption in ARL libraries, Hernandez Linares and Johnson (2016) found that $80 \%$ of ARL libraries were using LibGuides. In their study of the adoption of Web 2.0 tools by community colleges, Blummer and Kenton (2014) found that $78 \%$ of the 100 schools in their study offered LibGuides and that a number of the libraries studied used LibGuides as the platform for their websites. Internationally, a more recent survey by Bangani and Tshetsha (2019) found that roughly $70 \%$ of the public universities in South Africa were offering LibGuides to their communities. Recent data from Springshare suggests that there is even more widespread adoption of LibGuides and other Springshare software products (2021a).

While Springshare LibGuides has grown in popularity as a solution to hosting online library guides, LibGuides CMS has also slowly gained ground with those who found this to be an affordable and easy-to-use alternative for building and maintaining entire library websites (Ismail, 2012; Verbit \& Kline, 2011). LibGuides CMS is a website management platform that provides additional options beyond the basic Springshare LibGuides package. One facet of LibGuides CMS is "LibGuides Groups," a feature that allows libraries to customize subsets of LibGuides for specific groups and users. LibGuides Groups can also allow libraries to provide specific groups and users within the library community with the ability to create and design their own LibGuides (Hoffner \& Osuna-Garcia, 2020; 
SpringShare, 2021h). LibGuides CMS provides library subscribers with more sophisticated API (Application Programming Interface), CSS (Cascading Style Sheets), and JS (JavaScript) programming options as well as an LTI (Learning Tools Interoperability) App to allow greater coordination with a variety of courseware packages such as Blackboard, Canvas, and Moodle. The LibGuides CMS package allows libraries to create staff intranets and, of particular relevance for this study, design library websites (SpringShare, 2021h). Arguments for utilizing LibGuides CMS to design library websites include affordability, consistency, ease-of-maintenance, flexibility, membership in a large resource-sharing community, mobilefriendly format, positive user feedback, statistical features, and the ability to create a website without a large staff well versed in HTML and CSS (Desmarais \& Louderback, 2020; Enis, 2017; Libby \& Yaeger, 2017; Springshare, 2021e; Van Cleve, 2018).

Connell (2013) surveyed 265 research-level, Master's-level, and Baccalaureate-level academic libraries to determine if they were using a CMS to build and manage their library websites, and if so, what types of CMS they were using. Connell discovered that $64 \%$ of the libraries were using a CMS and that $5 \%$ were using LibGuides CMS. Seven different CMSs were noted by the respondents, with LibGuides CMS rated highest in satisfaction. While Connell found that utilization of CMSs by libraries was increasing, a number of libraries reported moving to a campus-wide mandated system that was not of their choosing.

Libraries and library professional organizations are now encouraging even more libraries to consider migrating their websites to LibGuides Content Management System (PANI, 2021). In an interview, Springshare CEO and inventor of LibGuides Slaven Zivkovic succinctly summarized this trend stating "We understand that LibGuides is not thought of as a website platform but we are working hard to dispel that notion and convince our libraries that they can host a very effective, affordable-and scalable-website using our LibGuides CMS platform" (Whitmer, 2017, p. 287).

Librarians have been creating public lists and descriptions of recommended library resources since at least the 1950s (Vileno, 2007), though some would argue that librarian-crafted bibliographies and book lists of the late 19th and early 20th centuries were the first precursors of the modern library guide (Smith, 2008). In 1972, Canfield and Stevens introduced what might be considered the original "library guide" in the form of a one-page print "Library Pathfinder" (Canfield, 1972). The purpose of the Library Pathfinder was to serve as "a compact guide to the user's basic information needs" (Stevens et al., 1973, p. 41). Jarvis (1985) found that pathfinders went by many different names including "library handouts," 
"bibliographic guides," and "LC Tracer Bullets." To increase visibility and to overcome the possible ambiguity of these various pathfinder labels, Jarvis encouraged libraries to host their pathfinders in online public access catalogs (OPACs) where they might be linked to the material to which they referred. With the development of web-linked search technologies Gopher and Veronica in the early 1990s, followed quickly by the explosive growth of the World Wide Web, librarians began moving their pathfinders and library guides to the internet to guide patrons to relevant library and internet resources and to provide a ready platform for bibliographic instruction (Diaz, 1998; Laverty, 1997; Schankman, 1994; Sloan, 1996).

In a 2002 study of 48 online business "pathfinders" at 20 Canadian and U.S. universities, Dunsmore discovered that there was a wide variety of names used to describe the library guides under consideration. The most prevalent keywords found in guide names were "research," "subject," and "guides," however, none of these business guides used the term "pathfinder." To overcome the inconsistencies in naming library guides, and to prevent potential patron confusion, Dunsmore argued for the name "subject guide."

In response to their 2003 usability study, which showed that undergraduate students seldom used "subject guides," the University of Rochester created the CoURse Resources System. This software allowed librarians to quickly create "course guides" that focused on the specific requirements of a particular course and thus might offer resources that proved more relevant to the students taking that course (Reeb \& Gibbons, 2004).

In 2009, a LibGuides Usability Task Force from the University of Michigan asked 16 students to choose three preferred names from a list of 15 possible library guide names (that did not include "LibGuides" as an option) and to indicate which of the names they disliked. The favorites included "Recommended Resources," "Research Resources," and "Research Guides." The most disliked names included "Cheat Sheets" and "MGuides" (Beaton et al., 2009).

In a 2010 study, Morris and Del Bosque studied the library guides of the 21 academic libraries of the Mountain West and Big 12 Athletic Conferences. They found that collectively these libraries used a variety of names for these guides. Fourteen libraries used two or more names for library guides and, in some instances, the same library guide was referred to by more than one guide-naming convention. The two most common names were "Subject Guide" and "Research Guide," though more complex combinations of these names were also discovered, such as "Research and Subject Guides." In total, the authors found there were 27 different guide names being used by these 21 libraries.

In their 2015 case study of LibGuides implementation at the University of Saskatchewan, Duncan, Lucky, and McLean noted that while the literature often refers to Springshare LibGuides as "LibGuides," they argued 
against listing library guides under this potentially ambiguous heading. LibGuides usability testing at the University of Alabama found that most students preferred the context relevant name "Research Guides" to the label LibGuides that was currently being used (Quintel, 2016).

\section{Methods}

In 2019, this study sought to evaluate the use of LibGuides among a large yet manageable set of distinct academic library populations. Colleges and universities from within the United States were chosen from four of the 33 Carnegie "Basic classification" categories arrayed under the 2019 Carnegie Standard Listings. While no two academic institutions are exactly alike, the Carnegie Classification System attempts to categorize similar schools based, in part, on the type and number of degrees awarded, research focus, enrollment, graduate-to-undergraduate ratios, and the nature of student residence on- or off-campus (Indiana University Center for Postsecondary Research, 2018). The "Basic classification" categories selected for this study included "M1: Master's Colleges \& Universities: Larger Programs," which is the category to which the researchers' home institution belonged; and "R1: Doctoral Universities-Very high research activity," which includes the majority of Association of Research Libraries (ARL) members. Baccalaureate-level and Associate's-level categories were also chosen to provide a broad array of institutions for this study. The Baccalaureate and Associate's-level categories were chosen for their high concentration of institutions from the researchers' state library organization. This generated an initial sample set of 834 institutions:

- 132 universities from the category "R1: Doctoral Universities-Very High Research Activity."

- 351 universities from the category "M1: Master's Colleges \& Universities-Larger Programs."

- 241 colleges from the category "Baccalaureate Colleges: Arts \& Sciences Focus."

- 112 colleges from the category "Associate's Colleges: Mixed Transfer/ Career \& Technical-High Traditional."

Each institution in the study was then analyzed to determine if there was a publicly accessible library website that provided library resources independent from other institutions. Institutions listed in the four chosen Carnegie categories were excluded from this study if:

- the institution did not offer a library website;

- the institution only allowed enrolled students access to the library website via password; 
- the institution was not clearly the primary author or owner of web-based library guides that appeared to be shared among other member institutions of an online consortial library; or

- the institution was a satellite campus of a larger parent organization and only offered web-based library guides that appeared to have been created or managed by that parent organization.

Of the initial 834 institutions selected, 17 Master's-level institutions, 18 Baccalaureate-level institutions, and two Associate's-level institutions were dropped for one or more of the conditions listed above. This left a study sample of 132 Doctoral-level institutions, 334 Master's-level institutions, 223 Baccalaureate-level institutions, and 110 Associate's-level institutions, for a total of 799 institutions.

For each of these 799 institutions, the primary library website was then located and the following five data points were recorded:

- number of library guides listed (LibGuides or other web-based library guides);

- whether Springshare LibGuides software was used to create the library guides;

- whether Springshare LibGuides software or LibGuides CMS software was used to create the library website-based upon either the presence of the word "libguides" in the URL of the guide or website, or the presence of a "Login to LibApps" access point at the bottom of the guide or website; and

- the name or names used to link to these guides from the library homepage or to describe these guides in the title of each library's primary library guide directory page (and exclusive of other names listed under "Type" by libraries using the LibGuides "Type" categorization).

\section{Results}

The most salient and immediate finding of this study is the confirmation of the prevalence of web-based library guides at American academic libraries and, more specifically, the predominance of Springshare's LibGuides platform. Of the 799 academic libraries analyzed by this study, 727 $(n=91.0 \%)$ offered web-based library guides, of which $655(n=82.0 \%)$ offered LibGuides. Of the 727 academic libraries offering web-based library guides, $678(n=84.9 \%)$ libraries either posted the total number of guides they offered or provided a ready means for tallying this total. Collectively, these 678 academic libraries offered 102,609 web-based library guides. All Doctoral-level institutions, $98 \%$ of Master's-level institutions, and $87 \%$ of Baccalaureate-level institutions, and $67 \%$ of Associate's-level institutions in 


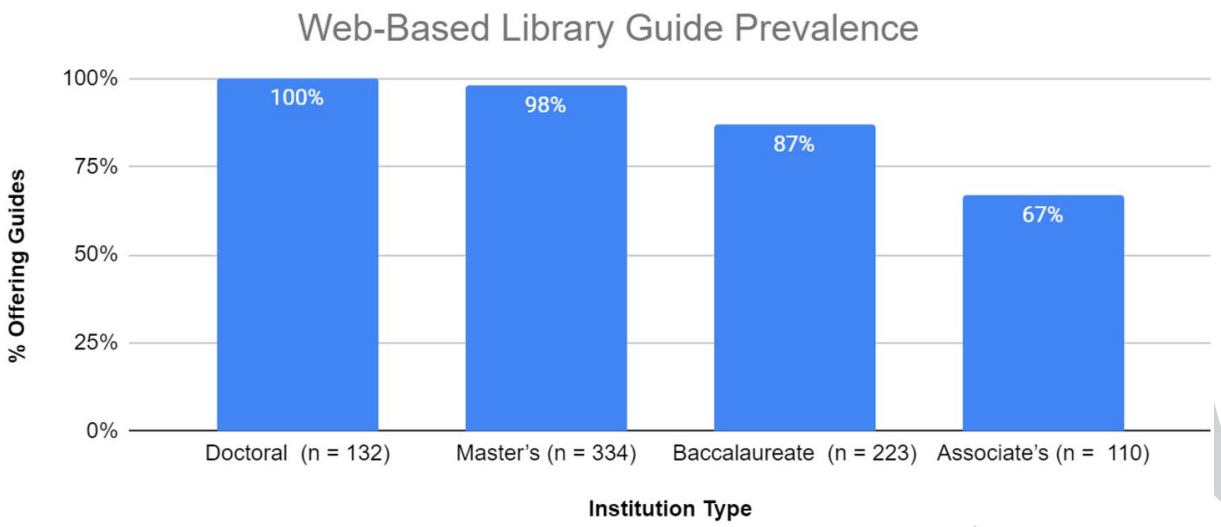

Figure 1. Prevalence of web-based library guides.

Average Number of Library Guides by Institution Type

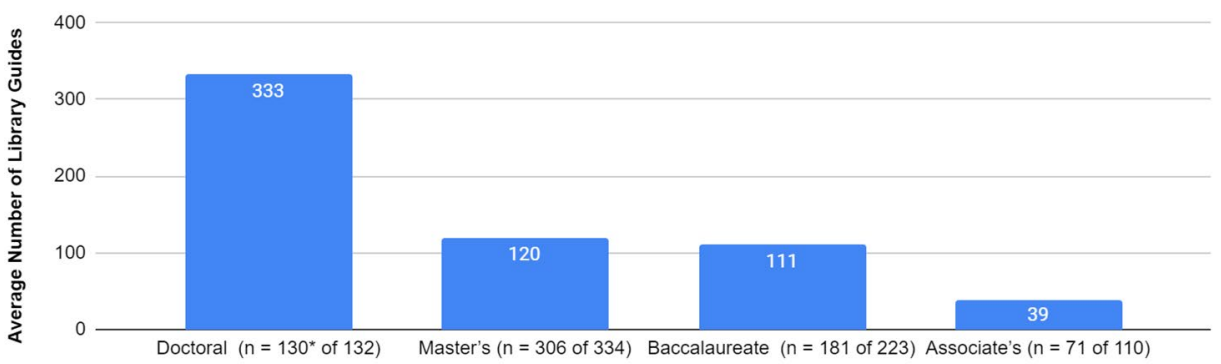

Institution Type

Figure 2. Mean number of library guides by institution type. ${ }^{*} n=$ number of schools that listed the total number of guides publicly available or provided a means for computing this number.

this study offered web-based library guides (see Figure 1). Web-based library guides are also produced in great quantity. In this study, the mean number of library guides offered was 333 guides for Doctoral-level institutions, 120 guides for Master's-level institutions, 111 guides for Baccalaureate-level institutions and 39 guides for Associate's-level institutions (see Figure 2).

The majority of institutions creating web-based library guides utilized Springshare's LibGuides software. Among larger institutions, 95\% of Doctoral-level institutions and $91 \%$ of Master's-level institutions offer LibGuides. Even $77 \%$ of the Baccalaureate-level institutions and $50 \%$ of the Associate's-level institutions provide their communities with LibGuides (see Figure 3).

A comparison of web-based library guide production for these institutions found that, on average, libraries using the LibGuides platform provided their communities with significantly more guides than those libraries that did not offer LibGuides (see Figure 4). Doctoral-level libraries that utilized 


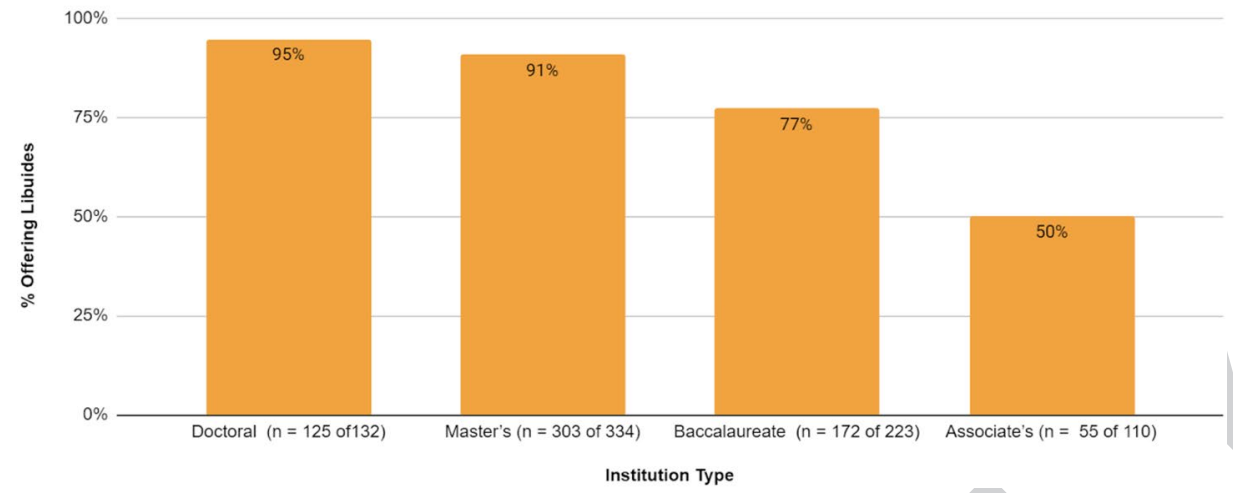

Figure 3. Schools offering LibGuides.

\section{Average Number of Guides Offered: LibGuides vs. Other Guides}

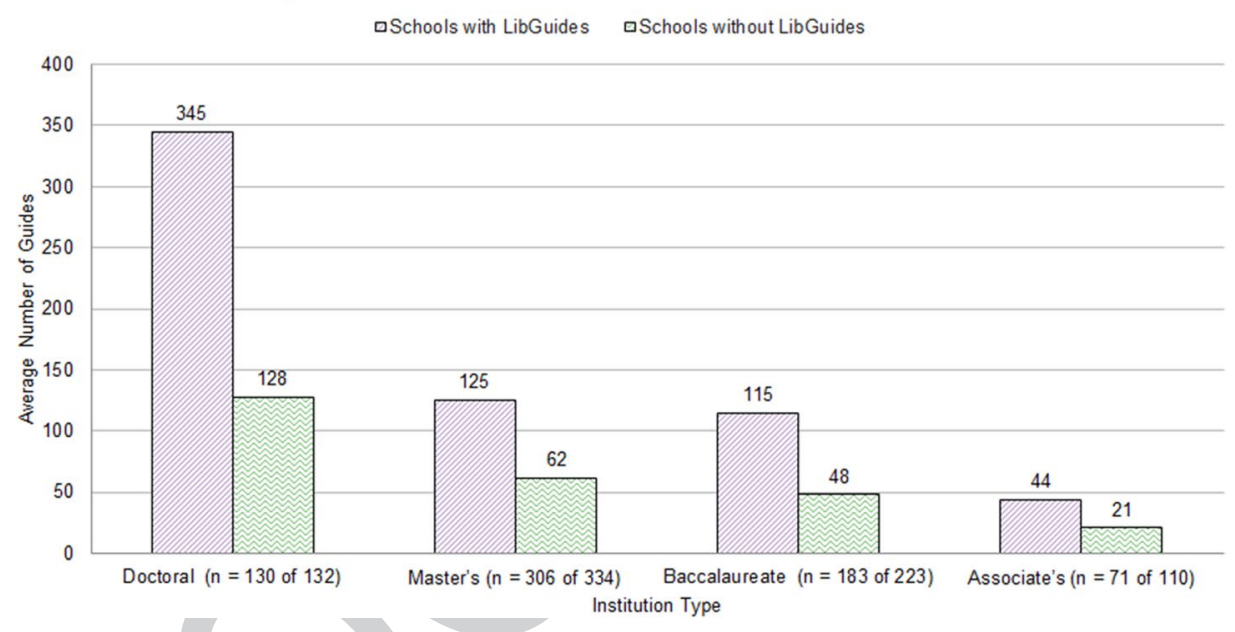

Figure 4. Number of guides Offered: LibGuides vs. other software. ${ }^{*} n=$ number of schools that listed the total number of guides publicly available or provided a means for computing this number.

LibGuides offered an average of nearly three times as many library guides to their institutions as those Doctoral-level libraries using other software-a mean of 345 guides vs. 128 guides. Master's-level, Baccalaureate-level, and Associate's-level libraries utilizing LibGuides offered on average roughly twice as many guides as their counterparts featuring library guides built with other software-a mean of 125 guides vs. 62 guides for Master's level libraries, a mean of 115 guides vs. 48 guides for Baccalaureate-level libraries, and a mean of 44 guides versus 21 guides for Associate's-level libraries.

This study found that a significant number of schools were using LibGuides CMS software to build their library websites. Though only $2 \%$ percent of the Doctoral-level institutions were using LibGuides CMS to host their websites, 
$75 \%$

$50 \%$

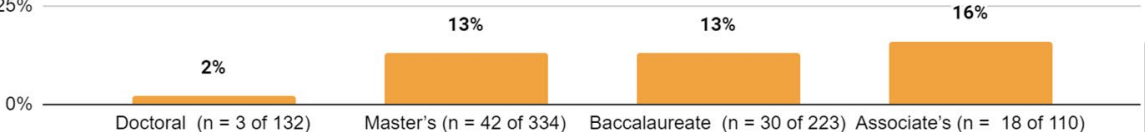

Institution Type

Figure 5. Library sites built mostly or entirely with LibGuides software.

$13 \%$ of Master's, $13 \%$ of Baccalaureate, and $16 \%$ of Associate's-level institutions in this study were found to be using LibGuides CMS to craft the majority of their library webpages (see Figure 5). However, for those libraries already offering LibGuides, the likelihood that the library website is powered by LibGuides CMS increases. Fourteen percent of Master's-level libraries offering LibGuides also construct their websites with LibGuides CMS. Similarly, 17\% of Baccalaureate-level libraries and 33\% of Associate's-level libraries that offer LibGuides also feature library websites built with LibGuides CMS.

More than $70 \%$ of libraries from each Carnegie category in this study used only one name to describe their guides on the library homepage or in the title or headers of their library guide directories. Twenty-seven percent of all Doctoral-level, 21\% of all Master's-level, 28\% of all Baccalaureate-level, and $15 \%$ of all Associate's-level libraries were found to use two or more library guide names on the library homepage or in the title or headers of their library guide directories-exclusive of additional names that may have been used under the LibGuides "Type" category offered by some libraries. A total of 952 official names were used by the 727 libraries that offered library guides in this study. While 52 different names for web-based library guides were identified on library homepages or in the titles and headers of primary library guide directories of each library, only four names predominated: "Research Guides," "Subject Guides," "Course Guides," and "LibGuides" (see Figure 6). The term "Research Guide" was clearly the most-common across all four Carnegie categories studied, with $69 \%$ of Doctoral-level, 56\% of Master's-level, 59\% of Baccalaureate-level, and $31 \%$ of Associate's-level libraries using this label. Other guide names that appeared regularly across all four Carnegie categories at a frequency of 1\%-5\% were "Library Guides," "Guides," "Resource Guides," and "Citation Guides." Two Doctoral-level libraries, three Master'slevel libraries, and four Baccalaureate-level libraries included either the 


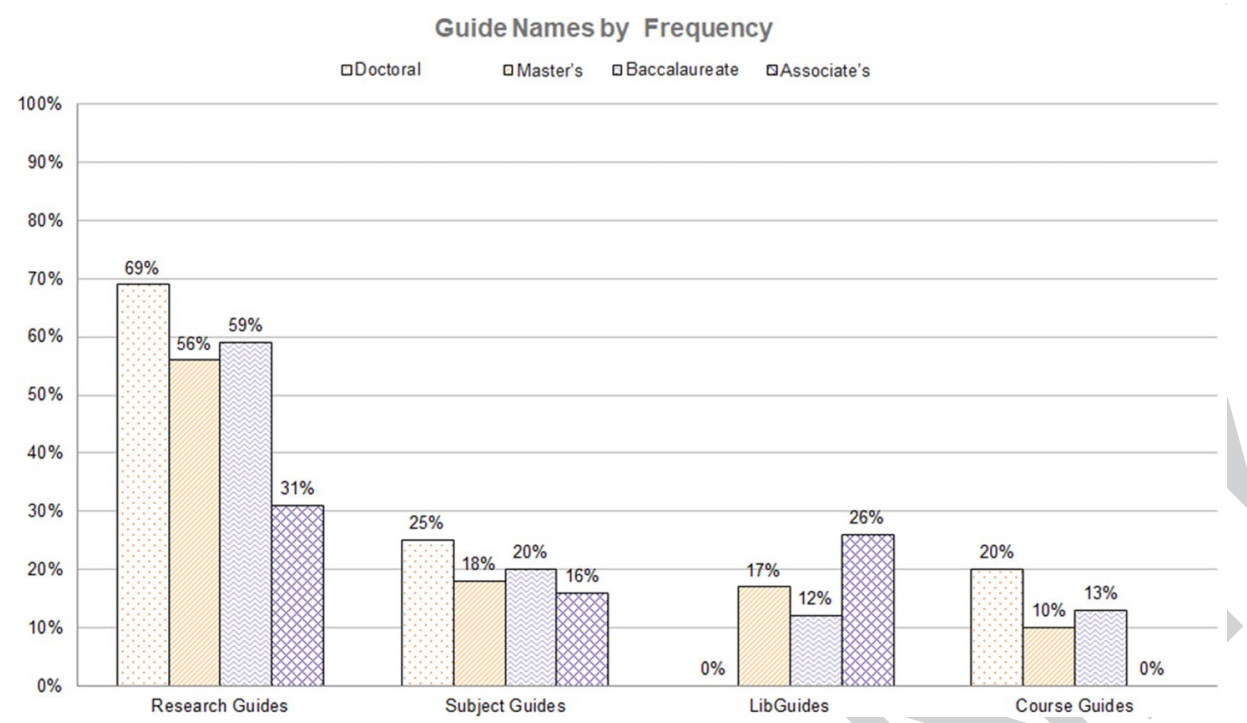

Figure 6. Guide names by frequency. ${ }^{*} \mathrm{n}=$ number of schools with named library guides. Percentages can add to either more than or less than $100 \%$ as many schools used both multiple names and other names for their guides.

name of the university, the library, or the school mascot as part of their naming scheme. Library historians should note that not a single institution in this study was using the once popular label "Pathfinder."

\section{Discussion}

This study found that LibGuides have come to almost completely dominate the library guide ecosystems of the Doctoral- and Master's-level libraries in this study. Three-fourths of all Baccalaureate-level and roughly half of all Associate's-level libraries in this study had also adopted LibGuides software. There are likely multiple reasons for the dominance of LibGuides in academia. LibGuides are easy to produce and can be applied to a variety of purposes. For situations that require a degree of consistency, LibGuides can be used to quickly replicate guides with similar appearances. Ease of production within the LibGuides system, coupled with increasing workloads and decreasing numbers of library staff, could also encourage a shift to the LibGuides platform. Libraries experiencing a decrease in IT support might look to Springshare for guidance or quick fixes for instructional needs as membership in the "LibGuides Community" provides an array of examples and contacts to aid the would-be library guide builder (Springshare, 2021d). Affordability might also play a role. LibGuides have been touted as inexpensive and affordable since their inception (Bolls et al., 2011; Hernandez, 2010; Pozzebon et al., 2008; Reese \& McCain, 2017; Sullivan, 2010; Whitmer, 2017). Still, others have noted the financial challenges 
associated with any commercial library guide system (Davis, 2013; Daws, 2016; Giullian \& Zitser, 2015). A subscription to any product or service can be one-too-many for institutions that are struggling financially. Smaller schools in this study, which might logically benefit the most from easyto-use Springshare products, were less likely to use LibGuides. This might indicate that cost and affordability are not straightforward variables and that even an inexpensive product might prove beyond the grasp of cashpoor libraries.

In their 2016 work, Jackson and Stacy-Bates note the historic technological advances in library guide production and presentation. Over the years, these guides have evolved from print handouts, to websites, and now to LibGuides. This evolution has allowed librarians to create and modify their guides with increasing ease and speed. One of the clearest disparities uncovered by this study was the difference in the number of library guides offered by libraries using LibGuides and the number of guides offered by libraries relying on non-LibGuides software. For the schools under consideration, the mean number of library guides publicly offered by libraries with LibGuides significantly eclipsed that of non-LibGuides institutions across each Carnegie category analyzed.

The number of library guides made publicly available on library websites may represent only a fraction of all guides created by a library. The LibGuides system offers multiple status options for library guides. LibGuides that are "published" are available to the general public. "Private" LibGuides are only available to those who know the URL for that guide. "Unpublished" LibGuides are unavailable to the public. For LibGuides CMS users, there is also a "submit for review guides" status where the guide remains offline until published by a reviewer (Springshare, 2021b). This study only tallied the "published" guides of each library. However, as LibGuides allows institutions to easily "unpublish" guides or make guides "private," many LibGuides may periodically disappear from public view at the end of school years, semesters, events, or courses. Thus, this study may well be underreporting what already appears to be a decisive LibGuides predominance in library guide production.

The library guide naming analysis in this study discovered that, as in 1985, 2002, and 2010 (Dunsmore, 2002; Jarvis, 1985; Morris \& Del Bosque, 2010), libraries continue to use a wide variety of labels for these resources. However, this study found that $77 \%$ of all the libraries used a single label to name their guides on their library homepage or in their primary library guide directory pages, a practice advocated for by Dunsmore. Though Dunsmore championed the term "Subject Guide," a label used by $20 \%$ of the libraries in this study, the name "Research Guide" won out across all 
categories with $58 \%$ of all libraries opting for this guide name. Use of the label "Research Guide" varied from a high of 70\% among research-focused Doctoral-level libraries to just 31\% among Associate's-level libraries.

For some schools, Springshare software has become an alternative to other website-building software for the construction of library websites. Springshare suggests and encourages libraries to consider LibGuides CMS as a website alternative, noting on their Springshare Buzz newsletter "LibGuides CMS addresses all of your website concerns and provides a simple, easy to use, and affordable 'out of the box' library website solution" (Springshare, 2021g, para. 2). Though not an exhaustive list, Springshare now features a directory of more than 40 academic libraries that have created websites based on LibGuides CMS. This SpringShare Buzz website "Academic Library Examples" also provides testimonials and interviews with librarians involved in the adoption of LibGuides CMS (Springshare, 2021f).

This study found that more than $10 \%$ of all Master's, Baccalaureate, and Associate's-level libraries reviewed had opted to build the majority of their library website using LibGuides software. That percentage could well have been higher. This study simply used either the presence of the word "libguides" in the URL of the guide or website, or the presence of a "Login to LibApps" access point at the bottom of the guide or website to determine if the website was powered by LibGuides CMS. However, as noted by librarians on the Springshare webpage "Power Your Website with LibGuides CMS: Academic Library Examples-Unabridged Interviews," it is possible to create websites that bear little resemblance to LibGuides and leave no obvious trace as to their LibGuides CMS origins (Springshare, 2021f). Using these methods for detecting LibGuides CMS, the research team was only able to detect LibGuides CMS indicators for 34 out of 46 (or 74\%) of the libraries listed as having LibGuides CMS websites on the Springshare webpage "Power Your Website with LibGuides CMS: Academic Library Examples-A-Z List" (Springshare, 2021e). If this sub-group of libraries is typical of all libraries, then the inspection method utilized in this study undercounted the number of libraries using LibGuides CMS to create their websites. Adjusting for a $74 \%$ detection rate would mean that perhaps as many as $17 \%-20 \%$ of the Master's-level, Baccalaureate-level, and Associate'slevel libraries were designing their websites with LibGuides CMS.

Yet even if as many as $20 \%$ of libraries from a given Carnegie category were using LibGuides CMS, this is just a fraction of the libraries using Springshare for their library guides. Why are there not more schools taking advantage of LibGuides CMS? It might seem logical that the same cost, technical-support, and time-saving issues that could be influencing the migration to Springshare LibGuides would play a similar role for libraries confronted with the maintenance or redesign of their entire webspace. 
Research by Kim (2011) into the various factors influencing academic library website design found that gathering advice from other web design experts was a significant need. As Springshare prides itself in providing direct and community support to subscribers, this should be an incentive to consider LibGuides CMS. Kim also showed that copying ideas from other university websites was a strong factor in website design. Since Springshare encourages the sharing of design ideas among its subscribers, this could be another argument for LibGuides CMS adoption. However, the vast majority of libraries is not adopting a LibGuides CMS approach. Perhaps there simply is not yet a large enough body of LibGuides CMS users to inspire confidence or provide enough examples for consideration? Complying with institutional website design guidelines was a factor that Kim found often played a key role in library website design. Thus, the strongest countervailing force to website building with LibGuides CMS may be the need for libraries to conform to university web design guidelines and policies. Library websites designed with LibGuides CMS may prove unacceptable to institutional administrators. In addition, the design and maintenance of the library website might fall to those outside the library who have little interest in or familiarity with LibGuides CMS.

\section{Limitations}

The ongoing implementation, application, and evolution of library guides make studying this area challenging, with many variables that prove to be moving targets. This study was conducted at a time-the summer break for many North American institutions-when some guides may have been removed from public view.

Different practices for naming and grouping LibGuides, as well as variation in the reporting of the total number of LibGuides, proved a challenge for this research as well. A significant fraction of libraries that offered LibGuides did not provide a tally of the number of LibGuides available to the public, necessitating some time-consuming detective work on the part of the researchers. As noted in the previous section, the inspection methods used to determine if libraries were using LibGuides CMS software to build their library websites appeared to have only a $74 \%$ success rate. Therefore, it is quite possible that LibGuides CMS was being used to build websites at slightly higher rates than detected by this study. A direct survey of library webmasters in the manner of Connell (2013) would definitively identify instances where websites were built with LibGuides CMS for all cases that received a survey response (Connell was able to obtain a $40 \%$ response rate), though this would be a labor-intensive and time-consuming endeavor. 
This study excluded those schools whose libraries' lack a publicly visible web-presence. This study also reached a compromise to resolve the problem of measuring and comparing LibGuides use for groups of institutions sharing a common library or set of online resources (e.g. a consortium of Doctoral, Master's, Baccalaureate, and Associate's-level institutions). In these cases, this study only considered the largest of the institutions and excluded all other associated schools. Finally, though this study considered nearly 800 academic libraries, this only represented four of the 33 Carnegie "Basic classification" categories.

\section{Future directions}

Though this study looked at some of the factors of web-based library guide application and use in academic libraries, there are numerous other variables that also deserve attention. For instance, to what degree are web-based library guides accessible to those with various disabilities? Several authors (Bergstrom-Lynch, 2019; Gonzalez \& Westbrock, 2010; Goodsett et al., 2020) have put forth sets of best practices for LibGuides design. These would allow for a comprehensive analysis of best practice implementation across a spectrum of institutions. Likewise, groups of academic libraries could be studied to see to what degree their LibGuides or other web-based library guides meet new accessibility standards. Giullian and Zitser (2015) argue that many library guides foster a digital divide as they serve primarily as conduits to expensive library-purchased resources accessible only to members of a particular academic community. This too could be considered in greater detail by perhaps measuring the fraction of the content of library guides that is open access.

This study was conducted in a pre-COVID-19 environment. If, as a result of the pandemic, there was higher demand for online library resources that can be safely used at a distance, the creation of library guides could well have increased significantly. A follow-up study of library guide numbers could provide some insight into the response to this crisis.

This study included a tally of websites crafted with LibGuides CMS. A follow-up study could measure whether this is a trend and, if so, how rapidly it is accelerating. A more qualitative study similar to that conducted by Connell (2013) would perhaps provide greater accuracy and complement this information by providing insights into why libraries are choosing this option.

Though this study more clearly defined the details of LibGuides adoption among a selected array of academic libraries, there are many questions yet to be answered regarding this very popular resource. As academic institutions face economic stress, libraries are increasingly under pressure to prove the value of their resources and services. Demonstrating the 
benefits of LibGuides could thus be considered an increasing research priority.

This study has helped demonstrate the degree to which Springshare's LibGuides has become the dominant library guide software in academia. A skeptic might ask if widespread adoption of this one software product will discourage experimentation and innovation, or expose the academic library world to yet one more monopolistic practice. An optimist might ask instead if near-universally adopted software creates greater opportunities for shared experiences and the development of a community of practice and understanding. Time, experience, and perhaps future research may answer these questions as well.

\section{Notes on contributors}

C. Neuhaus is an associate professor and instruction and liaison librarian at the University of Northern Iowa.

A. Cox is an assistant professor, instruction and liaison librarian, and Research and User Services Coordinator at the University of Northern Iowa.

A. Marie Gruber is an associate professor and instruction and liaison librarian at the University of Northern Iowa.

J. Kelly is an assistant professor and instruction and liaison librarian at the University of Northern Iowa.

H. Koh is an assistant professor and Assessment Librarian at the University of Northern Iowa.

C. Bowling is a Library Assistant III at the University of Northern Iowa.

G. Bunz is Learning Commons Coordinator at the University of Northern Iowa.

\section{References}

Bangani, S., \& Tshetsha, V. (2019). The deployment and impact of Libguides at public universities in South Africa. International Information \& Library Review, 51(2), 107-119. doi: $10.1080 / 10572317.2018 .1471963$.

Barker, A. E., \& Hoffman, A. T. (2021). Student-centered design: Creating LibGuides students Q3 can actually use. College \& Research Libraries, 82(1), 75-91. doi: 10.5860/crl.82.1.75.

Beaton, B., Bonnet, J., Dueber, B., Desai, S., \& Piacentine, J. (2009, November). LibGuides guerrilla testing: Usability report. University of Michigan Libraries. https://apps.lib.umich. edu/files/services/usability/libguides_rept_final.pdf

Bergstrom-Lynch, Y. (2019). LibGuides by design: Using instructional design principles and user-centered studies to develop best practices. Public Services Quarterly, 15(3), 205-223. doi: 10.1080/15228959.2019.1632245.

Blummer, B., \& Kenton, J. M. (2014). The availability of Web 2.0 tools from community college libraries' websites serving large student bodies. Community \& Junior College Libraries, 20(3-4), 75-104. doi: 10.1080/02763915.2015.1056703.

Bolls, M., Cho, C., Deegan, E., Dodson, E., Pattison, V., Sprigings, J., Gunn, K. (2011, February 25). Student as Teacher: Creating LibGuides as a tool for professional development 
[Conference Poster presentation]. 2011 CUA SLIS Symposium.https://cuislandora.wrlc.org/ islandora/object/cuislandora\%3A212886/datastream/OBJ/download/Student_as_Teacher_creating_LibGuides_a_tool_for_professional_development.pdf

Bowen, A. (2012). A LibGuides presence in a Blackboard environment. Reference Services Review, 40(3), 449-468. doi: 10.1108/00907321211254698.

Bowen, A. (2014). LibGuides and web-based library guides in comparison: Is there a pedagogical advantage?Journal of Web Librarianship, 8(2), 147-171. doi: 10.1080/19322909.2014.903709.

Canfield, M. P. (1972). Instructional materials: Design and development. Library pathfinders. Drexel Library Quarterly, 8(3), 287-300.

Cannon-Rech, D., \& Mortimore, J. (2020). Creating and Hosting OER Using LibGuides [Conference Presentation], Springshare Springy Camp 2020 Online. https://digitalcommons.georgiasouthern.edu/lib-facpresent/139

Chee, M., \& Weaver, K. D. (2021). Meeting a higher standard: A case study of accessibility compliance in LibGuides upon the adoption of WCAG 2.0 guidelines. Journal of

Q4 Web Librarianship, 1-21. doi: 10.1080/19322909.2021.1907267.

Conerton, K., \& Goldenstein, C. (2017). Making LibGuides work: Student interviews and usability tests. Internet Reference Services Quarterly, 22(1), 43-54. doi: 10.1080/ 10875301.2017.1290002.

Connell, R. S. (2013). Content management systems: Trends in academic libraries. Information Technology and Libraries, 32(2), 42-55. doi: 10.6017/ital.v32i2.4632.

Davis, S. D. (2013). Making the case campus-wide for purchasing LibGuides. In A.W. Dobbs, R.L. Sittler, \& D. Cook (Eds.), Using LibGuides to enhance library services (pp. 23-42). American Library Association.

Daws, C. (2016). Guiding your users to library resources: A case study of LibGuides at Charles Sturt University. ANZTLA EJournal, (17), 52-62. https://0-serials-atla-com.librarycatalog.

Q5 vts.edu/anztla/article/download/541/473 doi: 10.31046/anztla.v0i17.541.

Desmarais, B., \& Louderback, P. (2020). Planning and assessing patron experience and needs for an academic library website. Journal of Library Administration, 60(8), 966-977. doi: $10.1080 / 01930826.2020 .1820283$.

Diaz, K. R. (1998). The role of the library web site: A step beyond deli sandwiches. Reference \& User Services Quarterly, 38(1), 41-43. https://researchrepository.wvu.edu/ cgi/viewcontent.cgi?article $=1012 \&$ context $=$ lib_faculty

Duncan, V., Lucky, S., \& McLean, J. (2015). Implementing LibGuides 2: An academic case study. Journal of Electronic Resources Librarianship, 27(4), 248-258. doi: 10.1080/1941126X.2015.1092351.

Dunsmore, C. (2002). A qualitative study of web-mounted pathfinders created by academic business librarians. Libri, 52(3), 137-156. doi: 10.1515/LIBR.2002.137.

Enis, M. (2017, July). Hit refresh: Considering a website redesign? Check out these tips from library UX experts on how to organize a successful makeover. Library Journal, $142(12), 24-26$.

Ghaphery, J., \& White, E. (2008). Library use of web-based research guides. Information

Q6 Technology and Libraries, 31(1), 21-31. doi: 10.6017/ital.v31i1.1830.

Giullian, J. C., \& Zitser, E. A. (2015). Beyond Libguides: The past, present, and future of online research guides. Slavic \& East European Information Resources, 16(4), 170-180. doi: 10.1080/15228886.2015.1094718.

Gonzalez, A. C., \& Westbrock, T. (2010). Reaching out with LibGuides: Establishing a working set of best practices. Journal of Library Administration, 50(5-6), 638-656. doi: 10.1080/01930826.2010.488941. 
Goodsett, M., Nawalaniec, T. M., \& Miles, M. (2020). Reimagining research guidance: Using a comprehensive literature review to establish best practices for developing LibGuides. Evidence Based Library and Information Practice, 15(1), 218-225. doi: 10.18438/eblip29679.

Hernandez, J. (2010, March 12). Doing more with less: Using Web 2.0 to deliver more content via LibGuides.8th Annual Columbia University Libraries Reference Symposium, New York, NY. https://academiccommons.columbia.edu/doi/10.7916/D8DF6XZ7

Hicks, S., White, K., \& Behary, R. (2021). The correlation of LibGuides to print and electronic book usage: A method for assessing LibGuide usage. Journal of Web Librarianship, 15(1), 1-17. doi: 10.1080/19322909.2021.1884927.

Hoffner, C., \& Osuna-Garcia, A. (2020). LibGuides Groups in practice: Building a partnership between an academic library and an information studies school. College \& Research Libraries News, 81(4), 197-200. doi: 10.5860/crln.81.4.197.

Hooper, T. L. (2021). Accessibility and LibGuides in academic libraries. The Southeastern Librarian, 68(4), 12-28. https://digitalcommons.kennesaw.edu/cgi/viewcontent.cgi?article $=1904 \&$ context $=$ seln

Indiana University Center for Postsecondary Research. (2018). The basic classification description methodology. The Carnegie Classification Institutions of Higher Education, 2018 edition. https://carnegieclassifications.iu.edu/classification_descriptions/basic.php

Ismail, L. (2012). LibGuides CMS (formerly campus guides). The Charleston Advisor, 14(2), 35-39. doi: 10.5260/chara.14.2.35.

Jackson, R., \& Stacy-Bates, K. K. (2016). The enduring landscape of online subject research guides. Reference \& User Services Quarterly, 55(3), 219-229. doi: 10.5860/rusq.55n3.219.

Jarvis, W. E. (1985). Integrating subject pathfinders into online catalogs. Database, 8(1), 65-67. Kim, Y. M. (2011). Factors affecting university library website design. Information Technology and Libraries, 30(3), 99-107. doi: 10.6017/ital.v30i3.1768.

Laverty, C. Y. (1997). Library instruction on the web: Inventing options and opportunities. Internet Reference Services Quarterly, 2(2-3), 55-66. https://doi.org/10.4324/97804293529357 doi: 10.1300/J136v02n02_07.

Lee, Y. Y., \& Lowe, M. S. (2018). Building positive learning experiences through pedagogical research guide design. Journal of Web Librarianship, 12(4), 205-231. doi: 10.1080/19322909.2018.1499453.

Libby, A., \& Yaeger, J. (2017). LibGuides as a platform for designing a library homepage. Virginia Libraries, 62(1). doi: 10.21061/valib.v62i1.1463.

Linares, R. H., \& Johnson, A. M. (2016). Comparing apples to apples oranges: An exploration of the use of LibGuides in ARL libraries. The Southeastern Librarian, 64(1), 2-12. https://digitalcommons.kennesaw.edu/cgi/viewcontent.cgi?article=1616\&context=seln Magnuson, L. (2015, September 28). Accessibility testing LibGuides 2.0. ACRL Tech Connect. http://acrl.ala.org/techconnect/post/accessibility-testinglibguides-2-0

Morris, S. E., \& Del Bosque, D. (2010). Forgotten resources: Subject guides in the era of Web 2.0. Technical Services Quarterly, 27(2), 178-193. doi: 10.1080/07317130903547592.

Mortimore, J., Shepard, K., Smith, S. R., \& Cannon-Rech, D. N. (2020). LibGuides as the platform for hosting, curating, creating, and adapting Open Educational Materials. 2020 Georgia Libraries Conference, Virtual. https://whova.com/embedded/session/glcft_22011/1158543/

Ouellette, D. (2011). Subject guides in academic libraries: A user-centred study of uses and perceptions. Canadian Journal of Information and Library Science, 35(4), 436-451. doi: $10.1353 /$ ils.2011.0024. 
PANI [Private Academic Library Network of Indiana]. (2021). LibGuides website tips. https://libguides.palni.edu/LibGuidesWebsite

Pionke, J. J., \& Manson, J. (2018). Creating disability LibGuides with accessibility in mind. Journal of Web Librarianship, 12(1), 63-79. doi: 10.1080/19322909.2017.1396277.

Pozzebon, M. E., Wang, J., \& West, K. (2008). Providing and managing access to subject resources. Tennessee Libraries, 58(1), 1-7.

Quintel, D. F. (2016). LibGuides and usability: What our users want. Computers in Libraries, $36(1), 4-8$.

Reeb, B., \& Gibbons, S. (2004). Students, librarians, and subject guides: Improving a poor rate of return. Portal: Libraries and the Academy, 4(1), 123-130. doi: 10.1353/pla.2004.0020.

Reese, J. S., \& McCain, C. (2017). Special collections LibGuides: An analysis of uses and accessibility. Practical Academic Librarianship, 7(1), 1-12. https://journals.tdl.org/pal/ index.php/pal/article/view/7034/6113

Schankman, L. (1994). How to become an Internet power user.... College \& Research Libraries News, 55(11), 718-721. doi: 10.5860/crln.55.11.718.

Shotick, K. (2016). Access and universal design for learning in LibGuides 2.0. In A. W. Dobbs \& R. L. Stittler (Eds.), Integrating LibGuides into library websites (pp. 189-200). Rowman \& Littlefield.

Skaggs, D. (2016). Making LibGuides accessible to all. In A. W. Dobbs \& R. L. Stittler (Eds.), Integrating LibGuides into library websites (pp. 139-155). Rowman \& Littlefield.

Sloan, S. (1996). The virtual pathfinder: A World Wide Web guide to library research. Computers in Libraries, 16(4), 53-54.

Smith, M. (2008). 21st century readers' aids: Past history and future directions. Journal of Web Librarianship, 2(4), 511-523. doi: 10.1080/19322900802473886.

Sonsteby, A., \& DeJonghe, J. (2013). Usability testing, user-centered design, and LibGuides subject guides: A case study. Journal of Web Librarianship, 7(1), 83-94. doi: 10.1080/19322909.2013.747366.

Springshare. (2021a). About Springshare. https://springshare.com/about.html

Springshare. (2021b). Get help with LibGuides, CMS, \& e-reserves: Changing a guide's status to published, unpublished, or private. https://ask.springshare.com/libguides/faq/825

Springshare. (2021c). LibGuides. https://springshare.com/libguides/

Springshare. (2021d). LibGuides community. https://community.libguides.com/

Springshare. (2021e). Power your website with LibGuides CMS: Academic library examples - A-Z List. Springshare Buzz. https://buzz.springshare.com/producthighlights/libguidescms-as-website/academicexamples/az

Springshare. (2021f). Power your website with LibGuides CMS: Academic library examples - Unabridged interviews. Springshare Buzz. https://buzz.springshare.com/producthighlights/libguidescms-as-website/academicexamples/unabridged-interviews

Springshare. (2021g). Power your website with LibGuides CMS: LibGuides CMS solves your website needs. Springshare Buzz. https://buzz.springshare.com/producthighlights/ libguidescms-as-website

SpringShare. (2021h). Why subscribe to LibGuides CMS?Springshare Buzz. https://buzz. springshare.com/producthighlights/whylgcms/overview

Stevens, C. H., Canfield, M. P., \& Gardner, J. J. (1973). Library pathfinders: A new possibility for cooperative reference service. College \& Research Libraries, 34(1), 40-46. doi: 10.5860/crl_34_01_40.

Stevens, G. A. (2018). Flying without a Text: Using open educational resources, e-books, and LibGuides for nursing education.68th Annual Meeting of the Southern Chapter/ MLA, Orlando, Florida. https://dc.uthsc.edu/scmla/2018/poster2/5/ 
<smiles>C1#C[C@H](C2C#C2)C1</smiles> 